\title{
CHALLENGES FACED BY CHURCHES IN INCULCATION OF MORAL VALUES AND RESPONSIBILITY AMONG STUDENTS IN CHURCH SPONSORED SCHOOLS IN KENYA
}

\author{
SIMON KHAEMBA MAKOKHA ${ }^{1}$, JOASH MUTUA WAMBUA ${ }^{2}$ \& ROSEMARY \\ MBOGO $^{3}$ \\ ${ }^{1}$ Pastor in charge of Christian Education and Discipleship, Friends International Centre, Nairobi; \\ Part-time Tutor, Friends Theological College \\ P. O. Box 41946-00100 \\ Nairobi, Kenya. \\ ${ }^{2}$ Senior Lecturer and Director of the Doctor of Philosophy (Education) Program \\ Africa International University \\ P. O. Box 24686-00502 \\ Nairobi, Kenya \\ ${ }^{3}$ Associate Professor and Dean of the School of Education, Arts and Social Sciences \\ Africa International University \\ P. O. Box 24686-00502 \\ Nairobi, Kenya
}

https://doi.org/10.37602/IJSSMR.2020.3503

\begin{abstract}
This paper sought to investigate the challenges faced by the church in the inculcation of moral values and responsibility among students in church-sponsored schools. The study adopted a qualitative phenomenological design, with purposive stratified sampling along denominational lines being used in the selection of respondents. Five mainline churches that have sponsored schools for over five decades were considered for the study. Field data were collected from school principals, denominational education secretaries, and county education officers through interviews. Students and teachers were put together in separate focus group sessions each consisting of four to six participants. Participating students were drawn from form three and four classes. The study findings established that churches encountered various challenges in fulfilling their mandate of positively influencing the moral development of students in sponsored schools. Among the obstacles encountered were: resistance from some school administrations and some parents, conflicts with school administrations, and, regulation from either the school, the community, or from the government. In some instances, the church thought that they could contribute to the shaping of the moral dispositions of students but hurdles from within and without the schools stood in their way, making them do only what they were permitted to do.
\end{abstract}

Keywords: Obstacles, Challenges, Moral values, Behavior, Students, Responsibility, Church-sponsored schools.

\subsection{INTRODUCTION}




\section{International Journal of Social Sciences and Management Review}

World statistics show that youth of ages fifteen to thirty-five are the most vulnerable in matters of moral decay. While some acquire these traits at home, others learn from within their larger environments. Globally, young people, regardless of their colour, religion and wealth among other factors, are at risk of succumbing to vices of moral decadence. A report by the United Nations Economic and Social Council shows that in several countries, including the United States of America, the category of youth with the highest rates of suspected homicide perpetrators, are ages between 18-24 years and then 25-29 years, with males being the main perpetrators (UNESCO, 2016). Furthermore, the US Department of Justice, Federal Bureau of Investigation (2003) reports show that crime at the turn of the century was largely associated with young people of ages 16-25 years. The World Health Organization (WHO) statistics, on criminal activities, also give similar projections, only that the age range is between 10-29 years (WHO, 2016).

In Kenya, age-related concerns have not been any different. Reports of teenage pregnancies, drunkenness, drug abuse, truancy and other forms of moral corruption among the youth have been reported over and over again (BBC News, 2016; Fisher, 2001; Lagat, 2015; Ngunjiri, 2015; Oduor, 2016). Consequences such as dropping out of school, prostitution, loss of friends, abortions and infections from sexually transmitted diseases have been blamed on the curiosity of the youth, lack of advice, lack of knowledge, rape, poverty, overprotection and teacher-student love relationships which have resulted in school girls conceiving (Sang, Koros \& Bosire, 2013; Shahidul \& Karim, 2015; Kimani, 2013). Whether real or imagined, some have attributed vices such as students' protests, strikes and riots to failing school discipline (Tiego \& Kamore, 2014; Okayo, 2017). Parents too have been accused of contributing to the moral breakdown of young people. For instance, in a report of the National Crime Research Centre, in Kenya, it was reported that children born to members of criminal gangs are socialized into criminal lifestyles. According to the report, "criminal and wayward parents induct their children into such ways by using the children in spying, sneaking into closed houses to open them and conveying arms and drugs" (NCRC, 2012, p. 28)

Students in church-sponsored schools, even those that have been raised in Christian families, have not been left out of the way. When 550 school children were arrested in Eldoret, and 200 in Nairobi, 'raving', drinking, smoking, and allegedly having sex in a dimly lit disco, and a bar, some parents reported that their children had sought permission to go to church for various reasons (Lagat, 2015; Ngunjiri, 2015). Following those incidents, the government and other players in the field of education, including churches, worked tirelessly to try and instil moral uprightness in students. In the two instances, the students were all rounded up, taken to police stations, and then parents were brought in to identify and pick their children. Additionally, proprietors of those businesses were arrested for allowing students into the discos. These incidents, coupled with numerous concerns touching on the moral decadence of school-going children, suggest that efforts by the church and other stakeholders have not been adequate enough in eliminating the widespread and rampant cases of indiscipline amongst youth in Kenya. With school being one of the places where moral behaviour is taught, this paper ascertains the challenges that churches have encountered when instilling moral values and responsibility in students learning in church-sponsored secondary schools.

\subsection{REVIEW OF LITERATURE}




\section{International Journal of Social Sciences and Management Review}

In the Basic Education Act 2013, church-sponsored schools are recognized and entrenched in the law. In the Act, a sponsor is defined as "a person or institution that makes significant contribution and impact on the academic, financial, infrastructural and spiritual development of an institution of basic education" (RoK, 2013, p. 224). In article 27 of the Act, the sponsor is given roles that include: making recommendations on the review of the school syllabus, curriculum, books and teaching aids. The Act adds that the sponsor is to participate in the school management committees, supervise matters of spiritual development in the schools, offer chaplaincy services and extend financial support to its schools (RoK, 2013). From this Act, the role of supervising the spiritual development in schools, and offering chaplaincy services has been given to the sponsors. These roles revolve around the moral development in schools, spiritual growth and other pastoral services.

Moral development refers to forming a system of values on which one can base his/her reasons for doing good or bad (Ma, 2009). On the other hand, moral education facilitates the transmission of values that are central to enhancing cordial relations between persons. This education helps one to come up with sound moral decisions when faced with situations of the moral dilemma. Besides, moral education prepares the learner to reason and make good decisions that can satisfy most of the people. In this paper, morality is conceptualized from Christian and community perceptions. In the Christian view, morality encompasses all that is good, and not sinful. It includes right living, obeying God, servant-hood, respect for authority, humility, readiness to forgive, showing love and concern for others, and avoiding all manner of sins as described in the Bible (Galatians 5:19-21-26; Romans 13:13-14; Matthew Ch. 5-7). From the community view, morality consists of dispositions that are acceptable to the community. These include courage, truthfulness, honesty, respect, empathy, self-discipline, diligence, humanity, kind-heartedness, conscience, autonomy, responsibility, and, fairness in dealings, amongst many other qualities. Inclinations that go contrary to the scripture and expectations of the community, in this paper, are considered moral decadence.

Moral decadence among the youth can be said to originate from home, school, peer groups and the church (Munyua, Nyaga \& Oundo, 2014; Kombo, Ondicho \& Jepketer, 2018; Tiego $\&$ Kamore, 2014). The home, as the first place where values are taught to children, is central to a child's moral development. When, however, the home fails to play its role of instilling good values in children, other positive players in the child's life find it harder to instil good discipline in the child. Citing McCandles and Coop (1979, p. 241), Nanjero states that, "no one doubts that fathers who are available for their children and adolescents and take an active part in nurturing them contribute a great deal to their emotional, cognitive and social development" (Nanjero, 1998, p. 14). School, peer groups and the church, all build on what has been done at home. In some cases, however, they undo what was sown at home. "Bad company corrupts good morals" (I Corinthians 15:33).

In looking at various studies, Nyabwari, Michael and Daniel (2013) come close to addressing strategies employed by the church toward the moral development of pupils in Kenyan schools. In their study titled "Holistic Christian Education for Character Formation in Seventh-Day Adventist Church Sponsored Secondary Schools in Nyamira County, Kenya, Nyabwari, Michael and Daniel focused on character formation within Seventh Day Adventist (SDA) church schools (2013). Their study, which was limited to Nyamira County, explored the SDA church's educational philosophy and the efforts made to educate students for holistic Christian character formation. Their study also sought to examine the SDA practices that 


\section{International Journal of Social Sciences and Management Review}

were employed in implementing the church's educational philosophy, amongst other things. In contrast, the current study, which was a phenomenological study, took a multidenominational approach in identifying challenges faced by churches in instilling moral values in students within church-sponsored schools. While Nyabwari, Katola and Muindi focussed on one denomination, in one County-Nyamira County, the current study goes beyond a single County and studies a broader number of church denominations.

In another study, one that focused on students' indiscipline, Oteyo and Kariuki (2009) linked student's indiscipline, in schools, to drug use and abuse. In their study, Oteyo and Kariuki noted the crucial role the church plays in alleviating drug use and abuse. Whereas they did not focus keenly on challenges faced by the church in the moral development of students, they acknowledge the church's capacity to handle various moral challenges.

\subsection{MATERIALS AND METHODS}

The study was qualitative in nature and was limited to schools sponsored by churches in Kenya. The study adopted an exploratory qualitative research approach. The approach, which is also referred to as a formative research approach, emphasizes the discovery of ideas and insights (Kothari, 2004). The qualitative research approach is concerned with "phenomena relating to or involving quality or kind" and "assists when seeking to discover underlying motives and desires" (Kothari, 2004, p. 3). The qualitative approach, therefore, is about the subjective assessment of attitudes, opinions and behaviour; with the researcher's insights and impressions playing a key role in the process (Kothari, 2004; Patton, 2002).

The study employed in-depth open-ended interviews, direct observation and efforts to access written documents in the data collection. It also adopted a naturalistic qualitative method. This method allows for exploration and understanding of meanings that individuals or groups give to social or human problems and experiences (Creswell, 2014; Patton, 2002). The naturalistic qualitative approach enables the researcher to get right into the field, into the real world of programs, organizations, neighbourhoods, and so forth. In this approach the researcher gets close enough to the people and their circumstances, so he/she can understand the best (Patton, 2002). Through this approach, therefore, the researchers were able to identify the challenges faced by churches in inculcating moral values in students within church-sponsored schools. The naturalistic design was employed because it was viewed as adequate in enabling direct contact with participants for purposes of knowing the challenges of the church, based on their experiences and knowledge.

To know the challenges faced by the church in inculcating moral values in the students, it was assumed that the morality evidenced in students, in church-sponsored schools, could significantly be ascribed to the churches, as the spiritual and moral agents in the schools. Therefore, respondents were required to describe their individual experiences, and to give their subjective assessments on the churches' involvement in sponsored schools. The sampled church denominations were considered based on three grounds: first, each had its unique and specific boundary that defined its wholeness and unity; second, each had been a school sponsor for well over fifty years-suggesting well-developed structures and experience; and lastly, each had likely faced some form of challenge in executing their mandate in the sponsored schools. Field data were collected using different methods, and from multiple 


\section{International Journal of Social Sciences and Management Review}

sources so as to have a broader understanding (Creswell, 2014; Punch, 1998). This study, therefore, employed a multiple case approach, with the twelve interviews, and fifteen focus group sessions. Church education secretaries, school principals, and county education officers were interviewed individually, while teachers and students were put together in separate focus groups of between four to six participants in each.

The population of the study was at three levels, comprising of: first, the denominational leaders who participate in the formulation and implementation of policies in their sponsored schools; second, the school Principals, teachers and students in church-sponsored schools; and third, the county education officers from counties hosting the selected sponsored schools. With Kenya having 47 counties, approximately 5,000 sponsored secondary schools, and a handful of churches that have been school sponsors for over fifty years, sampling of the population was necessary. In this study, a stratified, purposive and convenience sampling strategy was applied. The strategy was applied due to the fact that the selected participants would provide information-rich data (Pathak, 2017). The denominations considered in the study included the Roman Catholic Church, Friends Church, Anglican Church, Presbyterian Church of East Africa (PCEA), Africa Inland Church (AIC), and Seventh Day Adventists (SDA) from which two sponsored schools were identified in each. The Africa Inland Church was later dropped from the study for logistical reasons.

Field data was collected using an interview protocol with eight semi-structured interview questions. The data from interviews, collected using an electronic audio recorder, was thereafter transcribed and then analysed using the qualitative data analysis software, Nvivo 12 Pro, student version. The findings of the study were thereafter presented in descriptive themes showing the challenges or obstacles that churches faced.

\subsection{RESULTS AND DISCUSSION}

The study sought to establish the challenges or obstacles that hindered the church's efforts in ensuring positive moral development of students in church-sponsored secondary schools in Kenya. The study findings indicated that churches encountered obstacles as they worked to fulfil their mandate in schools. In this study, 25 cases, out of the possible 27 showed that churches had experienced challenges in various ways. 63 pertinent snippets were analysed, with nine snippets, in six cases, showing that the church was limited in its role of moulding students because of financial and human resource. Of the nine snippets, four-pointed at limited finances, while five-pointed at limited human resources. The biggest obstacle that the church faced was resistance, conflicts, and regulation, either from the school community or from the government. In 23 cases, there were 54 snippets pointing at resistance from within the school, resistance or conflicts with neighbours, resistance from other churches and regulation from the government.

In the analysis, the field data yielded three sub-themes/ child nodes: 1) Resistance from neighbours, other churches, sects, and even from parents within the school. In this child node, 11 snippets, from ten cases, showed that the church had faced obstacles from neighbours, other churches and even from parents within the school, limiting what it could do to mould the students. 2) Resistance from within the school itself was the other sub-theme. Under this child node, there were 30 snippets drawn from 17 cases, indicating that the sponsor faced 


\section{International Journal of Social Sciences and Management Review}

Volume: 03, Issue: 05 "September - October 2020"

ISSN 2582-0176

obstacles from within the school itself; suggesting that the churches, though they were sponsors of the schools, did not have a free hand to mould students within the schools. 3) The last sub-theme in this category was resistance or regulation from government offices. This obstacle had 13 snippets, in eight cases, indicating that the sponsors had difficulties because of resistance or regulation from the government. This was significant because the same government that had allowed churches to be sponsors of schools was the same government that set regulations on what the sponsor could, or could not do. The three sub-themes, therefore, built a case to show that churches had experienced hindrances when seeking to ensure the moral development of students within their sponsored schools. Figure 1 is a word cloud showing the various words that were used by respondents, and the weights of their frequency.

Figure 1. Word cloud on obstacles faced by the church

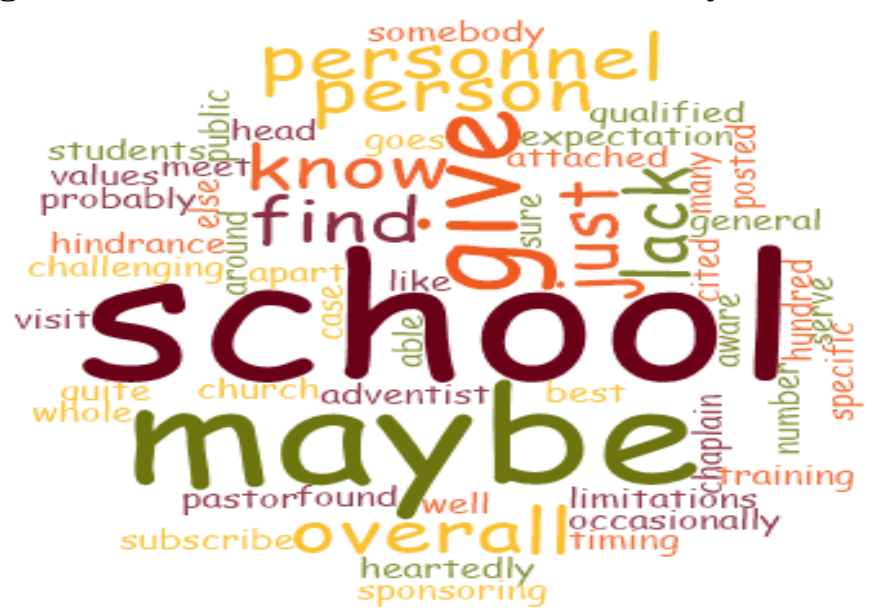

\section{Source: Field Data (2019)}

From the figure, the word used most frequently, by the respondents, was the word "school", likely because the study focus was on schools. The next word that was widely used was "maybe". While the word suggests uncertainty on what was said, the researchers understood it to suggest that respondents who used it were not insiders, and therefore, could only speculate on a given question. For instance, one of the questions in the interview protocol was: "What, if any, have been the obstacles hindering or limiting your sponsor's efforts in ensuring moral development of students in this school?" With this question posed to church leaders, school principals, teachers, students and county education officers, not all would be certain of the detail, and the word "maybe" was used in such contexts. The third word that was repeatedly used was "give". Next were the words personnel, person, lack, just, overall, know and find. Others that were pertinent to this study were: students, values, hindrance, challenging, visit, church, Adventist, pastor, sponsoring, limitations, occasionally, chaplains, training, able, apart, number, specific, general, posted, expectation, qualified, attached, aware, around, public, meet, many, timing, heartedly and somebody.

The other two challenges were inadequate human and inadequate financial resources. The study showed that due to the limited financial resources, most churches were unable to fully employ and, or deploy chaplains to all their sponsored schools. This meant that though a good number of schools were adequately served with chaplains, some were utterly left out of chaplaincy services. Alongside the challenge of inadequacy or shortage of chaplains was the 


\section{International Journal of Social Sciences and Management Review}

Volume: 03, Issue: 05 "September - October 2020"

ISSN 2582-0176

question of the competency of the chaplains themselves. Of the chaplains assigned to schools, a sizeable fraction could not match certain desired standards, especially where they could be assigned to teach Christian Religious Education (CRE).

On the part of resistance and regulation, this study showed that sponsors encountered resistance from other church denominations, students in the schools, people that were neighbours to the schools, and even parents within the schools. The strained relations, for instance between the sponsors and the school administration, could be summed up in the words of Wanyonyi, a church 4 school principal, who said that "...the relationship between the school administrator and the sponsor has at times been a big obstacle. The strained relationship can result from anything and everything" (Wanyonyi, personal communication, 2019). In this study, his words could tie in with other relationships that the sponsor had, meaning that conflicts and differences were a common occurrence. In addition to these challenges, the government had also laid down stringent rules on how the sponsor was expected to engage with the school. Table 1 outlines some of the challenges that school sponsors had to contend with when seeking to participate in the moulding of students in church-sponsored schools.

\section{Table 1. Challenges that school sponsors encountered in students' moral development}

\begin{tabular}{|c|c|}
\hline a & $\begin{array}{l}\text { Church faced by inadequate or lack of financial resources: -limiting their ability to run programs } \\
\text { or hire chaplains that would mould students. }\end{array}$ \\
\hline $\mathrm{b}$ & $\begin{array}{l}\text { Church had to go through school administrations for permission to do anything in their } \\
\text { sponsored schools. Some administrators were very negative and tried to keep the church from } \\
\text { the schools. }\end{array}$ \\
\hline c & $\begin{array}{l}\text { Church limited by either time, or large number of schools: - Because of the large numbers of } \\
\text { schools, and the limited numbers of chaplains, most churches could not give quality attention } \\
\text { to the schools. }\end{array}$ \\
\hline$d$ & $\begin{array}{l}\text { School activities and timetable, which may not be in harmony with church programs: - } \\
\text { Churches found it difficult to find openings within the school timetables, making it difficult for } \\
\text { them to carry out the desire to mould students. }\end{array}$ \\
\hline e & $\begin{array}{l}\text { Time given to church "too short", because of tight school schedule: - Churches were only to } \\
\text { operate within given slots; either on school parades, assemblies or other scheduled school } \\
\text { functions. }\end{array}$ \\
\hline$f$ & $\begin{array}{l}\text { School tradition: - Some sponsors could not push for principals from their denominations } \\
\text { because the schools argued that they had to keep their tradition of getting principals from } \\
\text { outside the denomination. Some schools had indiscipline as part of their tradition. }\end{array}$ \\
\hline g & $\begin{array}{l}\text { School rules have to be developed with students' participation: - No free hand for church- } \\
\text { meant that students had a significant voice in what goes on in the schools. }\end{array}$ \\
\hline $\mathrm{h}$ & $\begin{array}{l}\text { Some students resist sponsor due to their denominational affiliations back home: } \\
\text { Sponsor could therefore have very little impact on them. }\end{array}$ \\
\hline i & $\begin{array}{l}\text { Sponsor wants students' conversions; other stakeholders view that as secondary: - Sponsors' } \\
\text { time with students, and moral obligation was negatively affected by this position. }\end{array}$ \\
\hline j & $\begin{array}{l}\text { Sponsor can't discipline workers as neighbouring community defends its son/ daughter: - } \\
\text { Sponsors' hands were tied because the community around the school would react if certain } \\
\text { actions were taken against school workers from the community. }\end{array}$ \\
\hline $\mathrm{k}$ & Some students are just rebellious to church, school, parents, etc. \\
\hline I & $\begin{array}{l}\text { Students' hes } \\
\text { sceptical abo }\end{array}$ \\
\hline
\end{tabular}




\section{International Journal of Social Sciences and Management Review}

\begin{tabular}{|c|c|}
\hline $\mathrm{m}$ & $\begin{array}{l}\text { Some parents view church as a waste of time and instil the same in their children: - Some } \\
\text { children kept, or tried to keep off from spiritual things that were perceived as a waste of time. }\end{array}$ \\
\hline $\mathrm{n}$ & $\begin{array}{l}\text { Church members from other denominations try to pull down ideas by sponsor: - Sponsors were } \\
\text { countered by people from other denominations, with some disparaging what the school } \\
\text { sponsor tried to initiate as spiritual activities. }\end{array}$ \\
\hline 0 & $\begin{array}{l}\text { Encounters with devil worship, drug use, homosexuality amongst boys and girls, and } \\
\text { challenges from other religions }\end{array}$ \\
\hline$p$ & $\begin{array}{l}\text { Church representatives, in schools, lacking good public relations: - Some were not well received } \\
\text { either because of their personalities, education... etc. }\end{array}$ \\
\hline$q$ & $\begin{array}{l}\text { Church workers, like pastors and chaplains, lacking the necessary pedagogical skills since } \\
\text { church was limited in both human and financial resource: - In some cases, chaplains taught CRE } \\
\text { classes, while in some schools they had to speak to students and some did not know how to do } \\
\text { it. }\end{array}$ \\
\hline$r$ & $\begin{array}{l}\text { Strained resources as Ministry of Education could admit students above the school's capacity: - } \\
\text { Facilities meant for smaller numbers, such as chapels, were overwhelmed, having an impact on } \\
\text { what was initially planned. }\end{array}$ \\
\hline $\mathrm{s}$ & $\begin{array}{l}\text { Church has no control over choice, or character of students being admitted: - Both students } \\
\text { with good and bad character were admitted, with those of bad character posing a great } \\
\text { challenge to the churches' role of students' moral development. }\end{array}$ \\
\hline $\mathrm{t}$ & $\begin{array}{l}\text { Church: "spare the rod, spoil the child", and government: - "no corporal punishment": Two } \\
\text { different approaches: one a government policy, and the other a strategy that could be used } \\
\text { positively, according to the church. }\end{array}$ \\
\hline $\mathrm{u}$ & $\begin{array}{l}\text { Ministry does not give free hand to sponsors for them to do whatever they want: - sponsors } \\
\text { had to abide by government regulation, even where the suggested activity, creatively thought } \\
\text { through, was to be for the moral development of students }\end{array}$ \\
\hline $\mathrm{v}$ & $\begin{array}{l}\text { Delocalization and the posting of teachers, or principals, to or from the school: -sponsors felt it } \\
\text { when good teachers and principals were transferred elsewhere, or when they were denied } \\
\text { principals from their denominations, as these often brought conflicts. }\end{array}$ \\
\hline w & $\begin{array}{l}\text { Incidents of deviant teachers, with worrying morals practices, but delivering well in class: - } \\
\text { Sponsors could do very little against teachers with questionable morals; especially teachers } \\
\text { that were bringing. As to the school, because the administration and the community defended } \\
\text { them. The church had no power to sack, change, or punish them. Since only the Teachers } \\
\text { Service Commission (TSC) had authority to transfer teachers, sponsors and their moral } \\
\text { mandate were left with verv little to do }\end{array}$ \\
\hline
\end{tabular}

\section{Some of these challenges are further discussed below:}

\subsection{Limited finances}

This study revealed that several sponsors were faced with the challenge of limited financial resources. As much as they would desire to do great things for, or in their schools, they found themselves incapacitated. Johnston, a county education officer, disclosed that resources had been a big obstacle in the efforts made by the sponsor. He declared that:

We have had cases where the sponsor is willing to offer certain services, but is limited in terms of resources; and therefore, they demand for the school to pay for the services. Schools that are endowed pay, but others find it as a burden. At that level, the sponsor may be willing to go in, but since the school is not supporting the program, you find that the program is there, but not strong (Johnston, personal communication, 2019). 


\section{International Journal of Social Sciences and Management Review}

This thought was also shared by David, a church 3 school teacher. He said that on several occasions the church wanted to conduct an activity, but put it off because of financial limitations (Teacher David, personal communication, 2019). Teacher Jane, a church 2 school principal also concurred with the sentiments by saying that, "...the sponsor may not have enough resources, or even personnel to cope with issues that come up in our school setup" (Teacher Jane, personal communication, 2019).

The question of inadequate finances cuts across board albeit with varying degrees of intensity. Zadock, a church 4 education secretary disclosed that finances had been an obstacle when it came to helping pastors to become better chaplains. Therefore, one of the possible ways of going around the financial hurdle had been for the church to push the government's agenda of employing chaplains in all schools. He said, "...the churches have been trying to follow up with the government to see how the chaplains can be employed; because most of the churches don't have the resources to give them good salaries that can make them enjoy their work" (Zadock, personal communication, 2019). His generalization of "most of the churches" would be true if the absence of chaplains, in schools, was anything to go by.

\subsection{Limited human resource}

The study revealed that even in cases where funds were available, there were a good number of occasions when there were inadequate numbers of well-trained chaplains. The authors sought to find out the adequacy and competencies of the church workers. The interviewees showed that as much as there were many qualified church workers in the schools, there were also many others whose performance was wanting, and because of this, the sponsors were not able to fulfil what they wanted to do toward moulding the students spiritually and morally.

Among the obstacles that limited the sponsors' work, therefore, was the question of having insufficient and unqualified staff to oversee schools. Teacher Lynnette, a church 3 school principal, while making her assessment said, “...maybe they lack personnel, timing, or, the number of schools is too many that they are not able to visit all of them" (Teacher Lynnette, personal communication, 2019). She insinuated that, if the schools were too many, or if the church had very lean personnel or personnel that were overwhelmed by many more responsibilities, then chances would be high that the church would not operate optimally.

For Johnston, a County education officer, another obstacle that the county education office saw was the lack of proper pedagogical skills, on the part of church workers. Before presenting his case, he began with a question,

How do you deal with the learner? The way a pastor goes to preach to the general public, is not the same way he is going to preach to learners. In a school you do it differently because you find here there is a group that is almost homogeneous. They are at a particular place, for a particular purpose, for a particular period; and then even in terms of age differences, even in terms of behaviour, they are almost the same. So you can't go to them and be too general. If you are too general then you may not meet their specific needs (Johnston, personal communication, 2019). 


\section{International Journal of Social Sciences and Management Review}

Johnston went on to say that in a number of instances, the sponsor churches may have posted pastors or chaplains to serve the general public in an area; and the same persons were then attached to the schools, but they may not have had the specific training of ministry to students. Because of this, "...the person goes there wholeheartedly to give his or her best, and then does not meet the expectation of the students" (Johnston, personal communication, 2019). Johnston's case was one of the workers that were not adequately prepared, while the earlier challenge was of inadequate resources. Both situations made it difficult for the church to proficiently accomplish its mission of inculcating morals in students within its sponsored schools.

\subsection{Resistance or conflict with the school community}

The school community, in this study, was categorized into three: 1) the neighbours, other churches, sects and parents; 2) those within the school, and 3) the government. The nature of their resistance, regulations, or conflicts is shared below.

\subsubsection{Resistance from neighbours, other churches, sects and parents}

The study revealed that sponsors of schools faced different forms of resistance from communities related to the school. For instance, Teacher Teresia, from a church 1 school, reported:

Sponsors and schools, face difficulties because there are a good number of parents that bring their children who have never entered church; and more, a church they do not know. Some parents will see church services as activities that waste precious time (Teacher Teresia, personal communication, 2019).

For such parents, it would seem, the school should be about reading and concentrating on performance. Some parents, who had such minds, would even share their minds with their children. Therefore, Teacher Teresia added that children who come with such attitudes to school, "...embrace certain school gatherings with a lot of hindrances and opposition in the mind; it takes a bit longer to assist such children" (Teacher Teresia, personal communication, 2019). Nasimiyu, a church 4 school student, clarifies this further by saying that, "Also you find that some students are just rebellious to maybe school rules, to the spiritual fathers, and so forth; they are even rebellious to their parents." This makes the work of the sponsor fairly difficult (Nasimiyu, personal communication, 2019).

Nekesa, a church 4 school student adds, "Since the students come from different denominations, some of these do not take the Protestants seriously. So, as much as the sponsor may try to instil the moral values, they would not take it seriously. So, that tug-ofwar is still there" (Nekesa, personal communication, 2019). Thyrus, a church 1 school teacher, on his part lamented the lack of a direct link or contact between the sponsor and the parent. He said:

If they [sponsor] had several meetings with the parent, maybe it would be a step that would put the church and parents together. When the parent does it 


\section{International Journal of Social Sciences and Management Review}

on his or her own, the sponsor would not have any say. If there was that joint effort, I think it could be a good idea. You see when the sponsor wants to pass any information, they only pass it to the students and the parent does not get involved (Teacher Thyrus, personal communication, 2019).

For teacher Thyrus, sponsors and parents would do better if they met often and worked together toward shaping the students. In his view, failure to have several direct meetings was an obstacle to the efforts of the sponsor; and, the student could end up receiving different signals from the sponsor and from the parent. But if they were to jointly work toward the common goal, the impact would be greater and better.

Kiarie, a church 5 school teacher, was worried about the community around the school; that they were not involved in matters touching on students. For him, the community around the school was, “...very passive. Very passive! They might not care so much about student morals. It is like the students are left to the church" (Teacher Kiarie, personal communication, 2019). Teacher Jicho, from another church 5 school added that, "Some individuals in the society have a negative attitude; which when the sponsor wants to do one thing, they counter attack. Maybe, because they belong to another church, they want to shoot down ideas brought by the sponsor. I think that has been quite a problem" (Teacher Jicho, personal communication, 2019). Teacher Ken, a school principal, went ahead to say:

One of the obstacles has been the other churches. Now, like the SDA, when they say they don't want anything happening here on Saturday and we have students from Catholic or from wherever, they say they want to do their things; so now that becomes a problem. So, if they are denied that, the parents come complaining that the students are denied this and this and this, and yet they are not SDA (Teacher Ken, personal communication, 2019).

Teacher Salome, a church 1 school principal disclosed that challenges do not just come from parents and the government, but also from other stakeholders as well. She shared one of her experience by saying that, "....actually I got a letter at the end of last year; the letter was addressed to me from the Human Rights Commission, and the letter was telling me that they are writing because of a complaint by the Supreme Council of Kenya Muslims. They complained that their girls in this school are not allowed to wear hijabs. That if it is during Ramadhani they are not allowed to wear them..." (Teacher Salome, personal communication, 2019). This scenario presented the challenge of being a church sponsored school, but yet having students, and teachers, or staff, from other religious backgrounds. It is an inevitable reality that the church must take a position on. Her example showed that sponsors can get challenges from all quarters, including other stakeholders in the school, making the smooth flow of their work difficult.

Zadock, a church 4 education secretary acknowledged that there are times when the church's actions are resisted by the community, probably because the person facing disciplinary action comes from the community. Zadock said, "... when you want to stop him, they say now our child, or our son, is going to suffer. Such are the crossroads" (Zadock, personal communication, 2019). However, Zadock does not hesitate to add that the only way they had handled it was through involving the community. He observes that in such scenarios, the church goes back and asks the community, what do we do with this teacher, pastor, or 


\section{International Journal of Social Sciences and Management Review}

worker; seeing that it is our own children that he is spoiling? Then he answers, "Like acts of pregnancy from a teacher, is very serious; and I think even the community will not like that" (Zadock, personal communication, 2019). His prescription was not different from the one given by the church 1 school principal, when she was faced by the human rights proponents. For her, she also responded by bringing on board the other stakeholders. She did not want to make it an individual decision that had no stakeholders' participation.

\subsubsection{Resistance from within the school}

The study found that while some school members agreed that the church had faced obstacles when executing her roles in the schools, there were those who alleged that they had never seen the church facing obstacles. As Claudia, a church 2 school student put it, "I do not know of any obstacle" (Claudia, personal communication, 2019). A similar sentiment was expressed by teacher Lynnette, a school principal in a church 3 school. Her view was informed by the fact that the sponsor had kept a distance from the school, and so the sponsor may not really have known of, nor have had experiences of the said obstacles (Teacher Lynnette, personal communication, 2019). In addition, teacher Rose, a church 5 school principal did not see any obstacles that the sponsor faced. For her:

There is none. If they want anything, you just allow because we respect them as the sponsor; and I have not seen anybody limiting them or hindering them from anything that they wish to do in the compound, or with the students; even if they ask for the students, we give them (Teacher Rose, personal communication, 2019).

This sentiment from teacher Rose was informed by the way the sponsor had been active on the school's board of management. Because of that, most things that the school set out to do, the sponsor was already informed by virtue of actively participating on the school BoM. The schools, under normal circumstances had their own calendar, and timetables; however, there were times when the church would have liked to come in, for an activity, but found that there was no room. Oprah, a church 3 student, while identifying this obstacle stated that,

Let's say church 3 wants to follow the full programs of services that they usually have; then you find there is also a school timetable that indicates a specific time for worship and the rest of the time is for studies; so you find it is an obstacle in that they are not able to fully exercise the freedom of doing what they want to do (Oprah, personal communication, 2019).

Wangila, from church 4, concurred with sentiments made by Oprah, and added by saying that as much as the sponsor would have had good things to do, he first had to go through the school administration' otherwise, conflict would definitely be there (Wangila, personal communication, 2019). This thought was also built further by teacher David, from a church 3 school, who elaborated it saying that at times the church would come in with a list of things to do, but the school would be having its own activities in plan. In view of the pre-planned school activities, it would become very difficult for the school to give in. This was often so because school activities also involved other stakeholders such as parents and government offices (Teacher David, personal communication, 2019). While the government regulation 


\section{International Journal of Social Sciences and Management Review}

was the right policy procedure, it was at times used to censure the church and its planned activities.

Johnston, a County Education Officer agreed with the sentiments of the others by identifying the school program as an obstacle to what the church would have liked to do. In instances where the sponsors complained of limited time given by the school administrations, his take was that, "The school program may be too tight. So, probably the period that they are given is not enough for them to do what they want to do with the learners" (Johnston, personal communication, 2019). Therefore, the church could only scratch the surface, or do things in piecemeal, making the results of the church efforts less effective. Principal Jane, from church 2 agreed that the school programs are the ones that hindered sponsors from running their desired programs in the schools. For her, "...even if they [sponsors] wanted to have a program, maybe every day or every week, because of other programs in the school, they may not be able to do it" (Teacher Jane, personal communication, 2019).

Resistance to the church's efforts was also found in denominational differences. For instance, Becky, a student in a church 1 school verbalized that:

Not all students in this school are church 1 members. So you find that members who do not belong to church 1 do not want to participate in some of the things that have been organized; because they are done according to the church 1 doctrines. They feel they don't belong to church 1, and so they should not be forced to do those things (Becky, personal communication, 2019).

Rotchen, her colleague, added to Becky's thought by declaring that, "Some students who are not of church 1, as much as they would have liked to participate in activities of this church, have no idea of why these things have to be done; and at the same time have the dilemma of whether it will be right for them to start learning church 1 doctrines" (Rotchen, personal communication, 2019). On her part, Gurusha, a church 4 school student shared from the nonchurch 1 side by saying that, "We have students who come from different religions; they usually interfere with the time of going to church; they say they do not belong to that church, and that makes the sponsor church to face some challenges on how to control them" (Gurusha, personal communication, 2019). It indeed would be a precarious position since some students were guided, from home, not to go deep into practices of the sponsor denomination. Teacher Rose, from church 2 adds to the obstacle of denominational differences, by articulating it this way, "...church 2 would want to do things their church 2 way; but you find maybe the student with a certain issue is a church 1 or a church 5; so it is a major issue dealing with students from different backgrounds; and different upbringings are a challenge to the church" (Teacher Rose, personal communication, 2019). The whole question of denominational differences seemed to be common in all sponsored schools interviewed: Catholic, PCEA, Friends, SDA, and the ACK. Viora, a student from a church 5 sponsored school disclosed that, ". . . you see they [students] are mixed up [from different denominations], and the sponsor may decide to have a message to tell the church 5 students, so it hinders the sponsor because he cannot open up what he wanted to pass on to church 5 students in the presence of all the mixed up students" (Viora, personal communication, 2019). With challenges based on denominational differences, it becomes even a problem for sponsors to separate a few students so as to address them. Such a stance brings divisions in 


\section{International Journal of Social Sciences and Management Review}

the schools, and therefore the thought of moderated speeches that apply to all students become the only way out.

Anne, a County education officer, opined that when sponsors become very firm with their school rules, such as attending mass, "... in a way it sometimes brings conflicts particularly for those who do not subscribe to those religions" (Anne, personal communication, 2019). She went on to give the example of Christians and Muslims, in a church sponsored school, and said that their doctrinal differences had the potential of causing conflicts, even if each had their constitutional rights to choose the religion of their choice. In her words, "What is right for you may not be right for the other; and you are insisting that they must do it your way; it can bring some resistance in complying" (Anne, personal communication, 2019). In the course of ensuring that the people's constitutional rights are upheld, the sponsor would often take a step back so as not to offend those of the other faith. The net effect of this would then be that students cannot be subjected to similar rules and treatment from the sponsor.

From church 1, Teacher Francis elaborated by showing that denominational issues were so deep because even the teachers themselves were not from the same church denomination. On the students' side teacher Francis had the thought that, "...when the church is involved deeply in giving directions aimed at spirituality, some students feel as if that is not where they belong; that it is not what they were taught; making the church be limited" (Teacher Francis, personal communication, 2019). This would therefore suggest that the church needed to tone down for the sake of those of other beliefs. By toning down, however, it would mean that the sponsor could not do what was expected of him in terms of impacting the students. For Johnston, a county education officer, “....all public sponsored schools must be open to students from all denominations, and they should allow the students to attend church services regardless of their denomination, on the day that they have agreed on. For SDAs, most likely Saturday is the day. But for most denominations, Sunday, at a particular agreed time, is the time for worship" (Johnston, personal communication, 2019). Johnston went on to clarify that from the Ministry side there were provisions so that there was room for learners to have their programs under the clubs. He held that, "You will find in a school that we have the Christian Union, the Catholics also have Young Catholic Students YCS, and the SDAs also have theirs. In their small groups, they are again allowed to have their prayers and associations; fellowships which feature denomination specific traits: SDA, Catholic, or whatever groups" (Johnston, personal communication, 2019). Another county education officer, Michael, gave the example of the SDA schools, and said that sometimes, “...they don't allow students to do examinations or attend classes on Saturdays, or on Friday evening. So sometimes it becomes a challenge for the school to operate within its tight timelines..." (Michael, personal communication, 2019). For him, conflict with some teachers, students, and parents was there, against the sponsor, because of the strict Sabbath rules that require people not to do any work starting Friday evening till Saturday evening. Because of this, there were some quiet mummers against the rules, and practices of the sponsor.

The question of students' involvement in occult practices stood out as another internal obstacle to the church's mission. As teacher Nasimiyu, from church 4 put it:

...these days we have the spirit of devil worshipping. Students have been initiated into devil worshipping, so that though the church tries, it is an obstacle that souls cannot be won; so, 


\section{International Journal of Social Sciences and Management Review}

this becomes a hindrance. It is an obstacle because like these ones (devil worshippers) now want to win the souls, and you, the church, are also trying your level best... (Teacher Nasimiyu, personal communication, 2019).

Bahati, a church 4 student, reflected on a line similar to her teacher's, by saying that Christians are involved in a spiritual war with the devil. For her, the devil worshippers keep trying to compete with the school sponsor, and they oppose the work of the sponsor (Bahati, personal communication, 2019).

Churches that are invited to be sponsors of schools can find either a favourable or a hostile landing place. Public schools that have never had a sponsor before could use laid down procedures to get a sponsor for the school. However, once the sponsor is identified, and agreed upon, the sponsor would come in and probably find a school tradition that was not easy to handle. For instance, Johnston, an education officer says, "... if you get to a school and find the level of discipline is very high then you will go in and fit in; and if the discipline is not good then you will find that it is going to limit the extent you can reach" (Johnston, personal communication, 2019). In a welcoming and positive environment, the sponsors would fit well and do their work without a problem-leading to the transformation of many students. The contrary is true of a hostile environment until much effort has been put in to overcome the cause of hostilities.

On the part of students, Michael, a county education officer, declared that, “... a student is a student. Sometimes the students want to deviate to other things, and at times it becomes hard for the school to control. However, the students may want to do things beyond the regulation of the government; so they need to be brought back in line so that they don't go astray" (Michael, personal communication, 2019). Michael was of the view that there will always be students of wayward character; students that would give a hard time to the school authorities and school sponsors. For him, some of these students would influence others, thus making the work of the sponsors difficult. For such students, licentious living could become their standard if they were not controlled; and this was a challenge for the church to contend with. Besides the school tradition, there were cases where issues arose, because of changes in the leadership of the school. Though a school was a church sponsored school, the person coming in as the principal would not necessarily be a person of the sponsor denomination church. This often led to misunderstanding, and at times conflict. These scenarios were more common in schools where the principal and the sponsor were not of the same denominational background. For Johnston, a county education officer, "...from the office level, there are cases where sponsors come to complain that in this school, though we are the sponsors, we are not being given the real opportunity for us to be felt" (Johnston, personal communication, 2019); that as sponsors they were not being accorded the opportunities as they would expect. He also adds, however, that the very same way sponsors may have had problems with school principals, there were also cases where the school principals had issues with the sponsors. Johnston went on to clarify this by saying that, "...you find that once in a while the sponsors had conflict even with the management of the school. Where you find that maybe the church is asking for too much and the principal on the other side is saying no, up to this level; and then another time you find the principal does not even care for what the sponsor is doing" (Johnston, personal communication, 2019). These situations meant that the sponsor could not 


\section{International Journal of Social Sciences and Management Review}

have a good time to carry out the role of spiritual leadership, and moral guidance. On the contrary, the sponsor would be handled with some reservations.

Transitions were also a source of great conflict, and a hindrance to the church's ministry. Johnston, an education officer, argued that at the time of transferring chaplains, "The person in charge of the sponsoring, maybe the new chaplain or pastor, could come in with his own ideas, not necessarily like the former one had been operating. Again, friction and conflict would arise, because of the personality of the person representing the church, and what the church stands for" (Johnston, personal communication, 2019). His take, on the situation, was that the smooth continuity of the relationship between the school administration and the sponsor, after the transfer, would not be smooth in event that the transfers are not managed carefully. The ramifications of such a stance would leave students missing out on the guidance they ought to receive from the church.

Some churches had problems because of the focus they gave to spirituality. From the education office, Johnston contended that moral development of students and a spiritual commitment to Jesus were not necessarily one and the same. As a result, he was of the view that some sponsors experienced difficulties “...because some go in, and instead of bringing out the morals in the learners, they want to convert the learners. They go in and their message is you must accept Jesus Christ. So then at that level there is conflict between good morals to the learners, and just saying yes to Jesus" (Johnston, personal communication, 2019). His take, as a county education officer, and as a Christian, was that there was need to separate the two. In his assessment, “....some students would only like to know more about God, but not necessarily to be converted" (Johnston, personal communication, 2019).

\subsubsection{Resistance or regulation from government offices}

This study revealed that there were some differences between sponsors and the government, in terms of what the sponsor would have desired, as compared to the position that the government took. So that, at certain points the sponsor thought of doing things one way, but the government thought of the same thing but in another way. Teacher Teresia, a church 1 school teacher, used the example of form one selection in illustrating one of the differences. She believed that since the form one selection was being done by the Ministry of Education, the school had no much control over the nature and numbers of students that were sent to the school. She articulated her point by saying:

...from the number of students that the government sends in this school, they may send this year those who are not stubborn; there are chances you will want to reach to every child... But once the numbers increased, they were not likely to attend mass every day; it meant that some would have to miss, maybe even a week would end before they attend the mass; especially when there is no solution from the sponsor (Teacher Teresia, personal communication, 2019).

Teacher Teresia's thoughts were that the facilities that were available in school would not be able to absorb the increased number of students, and so they had to attend masses in shifts. For her, the best remedy would be to expand the current facilities so as to accommodate all 


\section{International Journal of Social Sciences and Management Review}

the students at a go, if possible (Teacher Teresia, personal communication, 2019). Teacher Teresia went on to say that when the numbers were so large, they, as teachers, were forced to remain at their tables, because of the congestion. Besides, when students went to the dining hall, they were made to queue, because they could not all fit in the dining room. This challenge then went back to the sponsor and the school administration, to try and see what could be done. The challenge revealed that even though the school and the sponsor, had planned well for a smaller number of students, they were forced to contend with a much larger number of students because the government selected and sent larger numbers of students to the school. Teacher Salome, a church 1 school principal, reported,

Right now you see, when it comes to admissions of students, it is not like during the independence days where the sponsor would determine who comes to learn at your institution. Now the admission is done by the Ministry. Right now, even like at form one, if you ask me who are church 1 members and who are not, I can't even tell you. Until we now sit down and check; and in any case, we don't divide them. It is anybody who is here to learn and gets the opportunity. So the sponsor does not have any permission to decide like, these are the people who will come to learn at the school (Teacher Salome, personal communication, 2019).

The principal, therefore, insinuated that the quantitative and the qualitative decisions on admissions, had been wrested away from the hands of the sponsor and the school administration, meaning that the school could not do things, or run their programs the way they had planned for themselves.

Teacher Jimmy, from a church 2 school, remarked that the government had put obstacles in the way of the church. While acknowledging excesses, of the sponsors, excesses that had been there in the past, he highlighted government policies, and said that the policies were limiting what the church and the school would have wanted to do. He decried some government policies, saying, "Because when you want to talk about disciplining a child, the government policy says that there should be no corporal punishment. So maybe the discipline issue, the discipline of the learners will become a challenge. From the end of the sponsor we consider discipline of the learners from a different standpoint" (Teacher Jimmy, personal communication, 2019) Teacher Mark, from a church 2 school, added to the voice on corporal punishment by saying, "For me, I don't think that the government has given the sponsor support because sometimes we look at disciplining the students, and the government looks at it like a barrier. Because the church is saying 'spare the rod and spoil the child' but the government is saying the opposite" (Teacher Mark, personal communication, 2019). Anne, a county education officer, supported the same thoughts as she declared that, "for the Christian, the rod is not a big deal, actually the rod is encouraged; it is still okay. But now from the Ministry of Education policy, corporal punishment has been banned. It is a policy issue, though for us, Christians, the use of a cane is not a big deal" (Anne, personal communication, 2019).

Johnston, another county education officer, went on to insist that even though churches would make efforts to do certain things, the Ministry had to regulate everything they did. He used an example to stress his point that churches could come up with their own stringent rules if given complete freedom over schools. He said, “...For example in the Education Act we 


\section{International Journal of Social Sciences and Management Review}

are not supposed to discriminate against learners. But if we give a lot of chance [to sponsors], the church may come in to make the school their own, and then they may come up with strict rules that will now be discriminating other learners who may not necessarily be members of their denomination" (Johnston, personal communication, 2019). He explained that, for example, the church could decide that there was no other worship to be allowed on the school compound, besides that which was conducted by the particular sponsor. Such a stance, to him, would disadvantage, or impact negatively, students from other denominations.

Teacher George's concern was with the usual posting and transfers of teachers. He said, "...the church may prefer that the teachers be of that denomination, but it is TSC which does that posting, and decides who to be there" (Teacher George, personal communication, 2019). He reflected on the question of delocalization of teachers, which he said had generated many emotions in the recent past. While some had appreciated it, other stakeholders had vigorously criticized it. He added that for churches having administrative staff and teachers that understood the church culture, faith and practice, would auger well, and some things would flow smoothly. However, when the TSC sent teachers that were not of the given denomination, conflicts were inevitable; as the teachers would want to embrace approaches that were not espoused by the sponsor. Ken, a school principal, opined that the Government, through the TSC, made them to go through difficulties. He stated that, "up to two years ago, the school was run by a principal who was not a church 5 member; and there were so many problems, because the principal wants to do things on Saturday that the sponsor does not want. This made conflicts between the sponsor and the school principal an endless debacle" (Ken, personal communication, 2019). As a result, service to the students, by the church, was affected.

On the part of school rules, Johnston, a county education officer, insisted that school rules had to be developed collectively. He noted, "... as much as we give them [sponsors] room to do this moral development, but in terms of rules we want all rules to be all inclusive where the learners are actively involved in coming up with the rules" (Johnston, personal communication, 2019). The implications were that the sponsor could not come up with rules single handed. Johnston then went on to identify concerns about students' performance after conversion. He revealed that, ".... in some schools, when the learners are converted, it also affects their performance; especially the religious subjects. That when you are converted, you cannot look at the Bible critically! According to some people when you look at the Bible critically it will be seen like you are trying to compare yourself to God" (Johnston, personal communication, 2019). In view of such outcomes, Johnston said that government regulation is inevitable, however much the churches would like freedom to operate in schools.

Having said that, there were cases where school sponsors felt that they could have had some power to do certain things, such as dismissing wayward teachers. Zadock, a church 4 education secretary, reported that there were times when you could have a very good teacher, one whose students do very well in his examination, but he, as a person, is not a good role model, morally. Consequently:

When as a church we want to take an action, maybe you recommend that the teacher has to be transferred, he is not transferred. Though you feel that this man should even be removed from the register, because of ruining children, nothing is done. So, such a case is now beyond 


\section{International Journal of Social Sciences and Management Review}

the church because TSC has the power, and we cannot just stop him. And we want peace; we cannot just tell the children to beat him or that (Zadock, personal communication, 2019).

Indeed, the study showed that there were situations where the church was torn between two or more decisions; situations where the sponsors found themselves in some kind of predicament. As a whole, the sponsors had faced different kinds of obstacles as they endeavoured to shape the young people into morally upright students. Human and financial resources were a challenge, with most denominations feeling the need for some financial assistance. School sponsors also had to contend with the question of government regulations in various quarters. So, as much as the sponsors may have had good ideas, and felt that they should have been given the full freedom, the Government wanted to give controls to the freedom. And even when the freedom was given, human and financial constraints made the church unable to efficiently and successfully implement what they would have liked to do toward the moral development of students in sponsored schools.

\subsection{The church's response in mitigating the challenges}

While the focus of this study was challenges faced by secondary school sponsors in the process of inculcating moral values in students, respondents also made remarks on how they had overcome the challenges. As a summary, however, in response to the many challenges that churches faced, and with the understanding that they still had to play their roles, school sponsors came up with various ways of ensuring continuity in their ministry. In the cases of conflict with school administrations, most sponsors came down and tried as much as possible to synchronize, or work out programs that could be agreed on with the schools. In the cases of conflict with the neighbours, capacity building and stakeholder participation were key in crafting a way forward. In some instances, the neighbours were given a challenge, in all its magnitude, and asked to give the way forward; thus absolving the sponsors and the schools from making the one decision that had to be made. In the conflicts that involved government regulations and laws, the sponsors often gave in, and also used the education offices as the starting point or as the place of refuge whenever disagreements existed between the churches and the schools. Some sponsors, however, had already put their houses in order by setting aside funds to pay their chaplains, and had also ensured that they had enough trained and qualified chaplains that could fill any vacancies in their sponsored schools.

\subsection{CONCLUSION}

The church, in its endeavour to transform students' morals, encountered various challenges, or limiting factors. These included things such as financial limitations, issues arising from denominational differences, resistance from the school communities and regulation from the government. However, through various approaches school sponsors were able to overcome the challenges. In some instances, the churches decided to come down and synchronize their programs with those of the schools, in others they decided on involving the various stakeholders, while in other cases they resorted to capacity building. The study, therefore, showed that school sponsors need to ensure good working relations with school administrations, work within laid down Government frameworks, and where possible to constructively engage stakeholders so as to bring concurrence and understanding in handling school matters. 


\section{International Journal of Social Sciences and Management Review}

Volume: 03, Issue: 05 “September - October 2020"

ISSN 2582-0176

\section{REFERENCES}

BBC News. (2016). Why are Kenyan schools being torched? 25 July 2016. http://www.bbc.com/news/world-africa-36845144

Creswell, J. W. (2014). Research design: qualitative, quantitative, and mixed methods approaches. Thousand Oaks, California: Sage Publications Ltd.

Fisher, I. (2001). 58 Youths Die in Kenyan Dormitory Fire. The New York Times. March 27, 2001.

http://www.nytimes.com/2001/03/27/world/58-youths-die-in-kenyan-dormitoryfire.html (Accessed July 2015).

Kimani, J. W. (2013). School factors influencing students' discipline in public secondary schools in Kinangop District, Kenya. (Unpublished Thesis). University of Nairobi. http://erepository.uonbi.ac.ke/bitstream/handle/11295/62989/Full\%20Text.pdf?sequen ce $=3$ (Accessed April 2019)

Kombo, K., Ondicho, K. N., \& Jepketer, A. (2018). Escalation of arson attacks in secondary schools and policy implications for education in Kenya. International Journal of Social Science and Humanities Research, 6(2). 361-371.

https://www.bing.com/search?q=escalation+of+arson+attacks+in+secondary+schools +and+policy+implications+for+education+in+kenya\&form=EDGEAR\&qs=PF\&cvid $=65 \mathrm{~b} 8 \mathrm{dc} 8 \mathrm{ae} 0984 \mathrm{cb} 8 \mathrm{a} 29 \mathrm{~b} 6920 \mathrm{c} 9 \mathrm{a} 716 \mathrm{e} 7 \& \mathrm{cc}=$ GB\&setlang=en-US (Accessed June 2019)

Kothari, C. R. (2004). Research methodology: Methods and techniques (second revised edition). New Delhi: New Age International (P) Limited, Publishers.

Lagat, C. (2015). Police arrest 550 students in sex, alcohol and drugs party in Eldoret. Daily Nation. Long, Robert and Paul Bolton. 2017. Faith schools in England: FAQs. Number 06972, 13 March 2017.

file:///C:/Users/Khaemba/Downloads/SN06972\%20(1).pdf

Ma, H. (2009). Moral development and moral education: an integrated approach. Educational Research Journal, 24(2), 293.

Munyua, M. M., Nyaga, V. K., \& Oundo, M. B. (2014). Selected factors contributing to alcoholism among secondary school students in Mwimbi division, Kenya. European Scientific Journal, 10(14), 373-379.

http://eujournal.org/index.php/esj/article/viewFile/3416/3180 (Accessed May 2019).

Nanjero, U. A. (1998). Adolescence: A study of discipline in selected secondary schools. M.

A. Thesis. Nairobi Evangelical Graduate School of Theology.

National Crime Research Centre. (2012). Summary of a study on organized criminal gangs in Kenya. Nairobi, Kenya: NCRS

Ngunjiri, J. (2015). Shock as students smoke bhang, drink booze on bus. Daily Nation.

August 7.

http://www.nation.co.ke/news/students-drug-party-on-bus/-/1056/2822836/-/j5cyvgz//index.html (Accessed December 3, 2015).

Nyabwari, B. G., Katola, M., \& Muindi, D. (2013). Holistic Christian Education for

Character Formation in Seventh-Day Adventist Church Sponsored Secondary Schools in Nyamira County, Kenya. International Journal of Academic Research in Progressive Education and Development, 2(1). ISSN: 2226-6348 (Accessed $31^{\text {st }}$ August 2016) 


\section{International Journal of Social Sciences and Management Review}

Oduor, A. (2016). Ministry report reveals causes of unrest in schools. The Standard. June 29th 2016.

https://www.standardmedia.co.ke/article/2000206930/ministry-report-reveals-causesof-unrest-in-schools (Accessed 5th June 2019).

Okayo, A., (2017). Factors influencing arson attacks in selected public boarding secondary schools in Trans-Nzoia County, Kenya. (M. A. research project). University of Nairobi (Unpublished Master's Thesis)

Oteyo, J., \& Kariuki, M. (2009). Extent to which selected factors contribute to alcohol and cigarette use among public day secondary school's male students: a case of Nakuru municipality, Kenya. Educational Research and Review 4(6), 327-333.

Patton, M. Q. (2002). Qualitative research \& evaluation methods. $3^{\text {rd }}$ ed. Thousand Oaks, California: Sage Publications.

Punch, K. F. (1998). Introduction to Social Research: quantitative and qualitative approaches. Thousand Oaks, California: Sage Publications.

RoK. (2013). Basic Education Act No. 14 of 2014. Revised edition. Nairobi: National Council for Law Reporting with the Authority of the Attorney-General

Sang, A. K., Koros, P. K., \& Bosire, J. N. (2013). An Analysis on Dropout Levels of Public Secondary Schools in Kericho District in Relation to Selected School Characteristics. International Education Studies, 6(7), 247-259 https://files.eric.ed.gov/fulltext/EJ1068455.pdf (Accessed May 2019).

Shahidul, S. M., \& Zehadul, K. A. H. M. (2015). Factors contributing to school dropout among the girls: a review of literature. European Journal of Research and Reflection in Educational Sciences.3(2), 25-34. http://www.idpublications.org/wp-content/uploads/2015/02/FACTORSCONTRIBUTING-TO-SCHOOL-DROPOUT-AMONG-THE-GIRLS.pdf (Accessed June 2019).

Tiego, P. M., \& Kamore, S. K. (2014). Factors leading to strikes and general indiscipline in high schools in Kenya: case of Murang'a County. Pinnacle Educational Research and Development, 2, no. 5, pp. 1-5. https://pjpub.org/perd/perd_147.pdf

U.S. Department of Justice, Federal Bureau of Investigation. (UCR Nov., 2003). Age-specific arrest rates and race-specific arrest rates for selected offenses, 1993-2001. file:///E:/age_race_specific\%20crime\%20in\%20usa.pdf (Accessed Aug 2015).

United Nations Economic and Social Council. (2016). https://www.unodc.org/documents/data-andanalysis/statistics/crime/ccpj/V1601819_EN_2016.pdf (Accessed 22nd June 2017)

Winter (2009). Hong Kong Educational Research Association. 